\title{
Measuring the sacrifice ratio Some international evidence
}

\author{
Kai Leitemo \\ Norwegian School of Management (BI) \\ and \\ Ole Bjørn Røste* \\ Norwegian University of Science and Technology
}

March 2005

\begin{abstract}
We estimate the output loss associated with deliberate disinflation - the sacrifice ratio - for six small open economies, through the simulation of estimated VAR models where the historical monetary policy has been identified. We estimate the sacrifice ratio before and after the introduction of explicit inflation targeting in Canada, Sweden and the United Kingdom, and compare estimates with similar periods for Norway, the Netherlands and Switzerland. The sacrifice ratios decline after the introduction of inflation targeting. We interpret this as evidence that inflation targeting has enhanced monetary policy credibility. Inflation targeting provides a robust, consistent and transparent policy framework that may have reduced the frequency of monetary policy surprises, and hence the output cost of low-inflation policies.
\end{abstract}

JEL-codes: E32, E52, E58.

Keywords: Disinflation costs, sacrifice ratio, VAR modeling, nominal inertia.

\footnotetext{
- We would like to thank Torben Andersen, Arne Jon Isachsen, Anders Vredin, Bernt Arne Ødegaard, two anonymous referees, and, in particular, Steinar Holden, for valuable comments and suggestions. We also thank participants at the Norwegian Economists Meeting 2002 for comments and suggestions to an earlier draft. The views presented and any errors remain the sole responsibility of the authors. * Corresponding author. Address: Norwegian University of Science and Technology, Department of sociology and political science, N-7491 Trondheim, Norway. Email: ole.bjorn.roste@svt.ntnu.no.
} 


\section{Introduction}

High and variable inflation may lead to welfare losses. Since the 1990s, economic policymakers have become increasingly concerned with inflation stabilization. This is reflected for instance by the introduction of explicit inflation targets for monetary policy in many industrialized countries. The increased focus on inflation stabilization by policy makers has contributed towards bringing inflation rates down from the high rates experienced in many countries in the 1970s and 1980s. However, disinflation policies and contractive monetary policy stances have often been associated with more or less persistent output reduction. An interesting question is whether the introduction of explicitly announced targets for inflation in some countries has reduced the costs of inflation stabilization, in particular reduced the sacrifice ratio, i.e. the accumulated output loss due to a permanent reduction in inflation of one percentage point. In this study, we provide some evidence in favor of an affirmative answer to this important question.

The sacrifice ratio may be used to proxy the relative success of policy regimes. A reduction in the sacrifice ratio following a regime change, could be a result of improved policy credibility for the inflation target or reduced nominal inertia, both of which would be beneficial to the working of the economy. Both a high degree of nominal inertia and a low credibility of inflation stabilization policies can imply an unfavorable trade-off between inflation and output stabilization and increase the costs associated with stabilizing inflation: the central bank would need to pursue a more aggressive monetary policy, working through lowering of marginal costs and decreases in aggregate demand to persuade private agents to reduce the growth rate of prices. Aggregate output could therefore fall short of its flexible-price value, and become more unstable.

We estimate sacrifice ratios for six countries, three of which introduced explicit inflation targeting in the first half of the 1990s (Canada, Sweden and the United Kingdom), and three that introduced inflation targeting much later (Norway and Switzerland) or entered the European Monetary Union (The Netherlands). Throughout the 1990s, Netherlands and Norway formally adhered to exchange-rate stabilization and Switzerland to monetary targeting. Note, however, that these regimes may have targeted inflation implicitly by providing stable unconditional expectations of inflation (as a nominal anchor), but without formally providing an explicitly announced point target of inflation as required for an inflation targeting regime (see, e.g., Svensson, 1997). For all countries, we estimate sacrifice ratios for two periods, a pre inflation targeting period and an inflation targeting period. The first period runs from the late 1970s to the introduction of inflation targeting by the three of 
the sample countries (around 1993). The second period runs from that point through 2003 (due to data availability). ${ }^{1}$

Our methodology allows us to measure the sacrifice ratio as the costs of a deliberate disinflation policy in contrast to, e.g., the output costs of a series of negative cost-push shocks. To derive our sacrifice ratio estimates, we first estimate vector autoregressive (VAR) models for the sample countries, for both the mentioned time periods. The VAR models identify the interest rate reaction function (i.e., the systematic part of the monetary policy) that has been pursued over the sample periods. We then simulate the estimated VAR models, to compute the sacrifice ratio from a disinflationary shock, while assuming that the economy was initially in steady state with an inflation rate one percentage point above the historical average. Using the VAR models with the historically identified monetary policy reaction functions, we evaluate the output loss as inflation is reduced to its historical average rate.

The use of the historically given interest rate reaction function is essential to our VAR analysis. The sacrifice ratio estimates will reflect the efficiency of the historical estimated policy. One could instead be tempted to derive optimal policies for the VAR models and then carry out the same disinflationary experiment in order to remove the effect of inefficiencies in policymaking across countries. However, the reduced-form nature of the identified VAR models does not allow this. The reason is that we expect the parameters of the VAR models to be sensitive to changes in policy, which would have made our analysis more vulnerable to the Lucas critique. This is also the rationale for estimating the VARs for the two periods separately: The monetary policy reaction function is thus allowed to change after the introduction of inflation targeting. Using the historically given interest rate reaction function, we implicitly assume that the historically given level of policy credibility applies when the central bank achieves the steady-state inflation rate.

To foreshadow our main result, most estimates suggest a fall in the sacrifice ratio for the three inflation-targeting countries after the introduction of explicit inflation targets. There is no such consistency in the evolvement of the sacrifice ratio for the other three countries. We interpret this as evidence that the explicit inflation targets have led to lower sacrifice ratios, through enhanced monetary policy credibility.

The remainder of the paper is structured as follows: Section two briefly reviews the literature on estimating sacrifice ratios. Section three discusses how the introduction of inflation

\footnotetext{
${ }^{1}$ For a detailed description of the time periods by country, see table 4.1 .
} 
targeting may have reduced the sacrifice ratios by adding credibility to the inflation rate targeted. Section four then presents the data, discusses our empirical modeling approach, and presents the estimated VAR models for the sample countries. Section five presents sacrifice ratio estimates computed by simulation of our empirical models, and section six provides some concluding remarks.

\section{A brief review of the empirical literature}

Early studies of the sacrifice ratio proceeded by estimating a Phillips curve - i.e. the relation between output and inflation in long time series (Okun, 1978; Gordon and King, 1982). In some later studies, sacrifice ratios have been estimated through simulation of VAR models (Cecchetti, 1994; Cecchetti and Rich, 2001; Corbo et al., 2001). Our methodology has most in common with Cecchetti and Rich (2001).

In an influential paper, Ball (1994a) argues that deliberate and accidental inflation reductions should not be treated equally, and that it may be problematic to constrain the sacrifice ratios to be constant within a time series. Ball thus identifies episodes of disinflation across countries and over time, with annual and quarterly data, attempting to capture the effects of deliberate disinflation. A unique sacrifice ratio is estimated for each disinflation episode. ${ }^{2}$ Benjamin Friedman's (1994) discussion in the same volume, points out that the peculiarities of the measurement of output lost under disinflations in Ball's study could either work to enlarge or shrink the resulting estimate of the sacrifice ratio for any episode, and that the latter seems more likely in view of the small average size of Ball's estimates.

A similar approach to Ball (1994a), focusing on episodes, is applied by Jordan (1997) in estimation on annual data of sacrifice ratios (during periods of disinflation) and "benefit ratios” (during periods of reflation). The entire sample is divided into inflation and disinflation periods. In contrast to Ball, Jordan does not a priori rule out the possibility that the data may carry important information on the output costs of disinflation in times where inflation is stable or rising. An important problem with the approaches to the sacrifice ratio of Ball (1994a) and Jordan (1997) is that all periods of disinflation are viewed as resulting from

\footnotetext{
2 Episodes of disinflation are identified based on an eight-quarter moving-average series of CPI inflation. An episode emerges whenever this series drops by more than two percentage points from its previous peak. Important assumptions in Ball's study are, first, that output is at its steady state level at the start of each disinflation episode, second, that output is again at trend four quarters after the end of a disinflation episode, and third, that there are no supply shocks. The totality of these assumptions may cast doubts on the generality of the results.
} 
demand-management policies, leaving no role for supply shocks. This is unrealistic, as supply and cost-push shocks are also known to influence price setting. ${ }^{3}$

More generally, the output effects of disinflation may differ depending on the factors that cause disinflation. For instance, the output effects of a reduction in inflation brought about through a series of negative cost-push shocks may be quite different compared to a situation where inflation is reduced through a reduction in aggregate demand. Since we focus on the output effects of a deliberate attempt by the policymaker to reduce inflation, a method that identifies the role that monetary policy plays is required. Our VAR method, which identifies the historical strategy the central banks have used in order to stabilize inflation, satisfies this requirement. Furthermore, our method does not suffer from the unavailability of test statistics associated with the more informal approaches.

Other studies in the VAR tradition have reported very large standard errors for the sacrifice ratio point estimates. Although the standard errors of our point estimates are large, they are smaller than in related VAR-based studies we are aware of. From a technical perspective, the parameter richness of VAR models makes parameter uncertainty increase rapidly in the size of the model, in terms of lag length and the number of endogenous variables (Cecchetti and Rich, 1999). Imprecise point estimates may also stem from imprecisely measured endogenous variables. For instance, potential output is rarely measured accurately. The finding of large standard errors should therefore not be surprising.

\section{Credibility, nominal inertia and the sacrifice ratio}

As noted above, the sacrifice ratio measures the cumulative output loss under disinflation for each percentage point reduction in the inflation rate, formally:

$S R=-\frac{\sum_{s=0}^{\infty} \delta^{s-t_{0}} E_{t_{0}}\left[\frac{Y_{t_{0}+s}-Y_{t_{0}+s}^{*}}{Y_{t_{0}+s}^{*}}\right]}{d \pi^{*} 100} \approx-\frac{\sum_{s=0}^{\infty} \delta^{s-t_{0}} E_{t_{0}}\left[\ln Y_{t_{0}+s}-\ln Y_{t_{0}+s}^{*}\right]}{d \pi^{*} 100}=-\frac{\sum_{s=0}^{\infty} \delta^{s-t_{0}} E_{t_{0}} X_{t_{0}+s}}{d \pi^{*} 100}$

where $t_{0}$ denotes the start of the disinflation period, $E_{t}$ is the expectations operator conditional on information at time $t, \delta$ is the discount factor, $Y$ is actual production, $Y^{*}$ is potential production, $x$ is the output gap and $d \pi$ is the change in the inflation rate over the period.

\footnotetext{
${ }^{3}$ However, estimates of sacrifice ratios by various methods for Canada reported by Johnson and Gerlich (2002) show that not explicitly allowing for supply shocks need not have severe consequences.
} 
What mechanism may give rise to high sacrifice ratios? New Keynesian theory (e.g., Taylor, 1979; Calvo, 1983; Clarida et al., 1999) suggests that prices are set in a staggered manner, and fixed for a certain time period. Price setters are concerned with how prices of competing goods are expected to develop - and thus of the future monetary policy stance. If it is costly to set a price that deviates from the prices of competing goods, firms are likely to change prices slowly in response to a given change in the monetary policy stance (see Ball and Romer, 1990). The degree of nominal inertia is thus a key determinant of the sacrifice ratio. However, since also the future matters, the price setters' expectation formation is a complementary factor. For instance, under rational expectations and assuming that monetary policy is expected to be contractive also in the future, price-setters will conclude that, for a given degree of nominal inertia, the benefits from adjusting prices are large. In this setting, overall nominal flexibility may be high and a contractive monetary-policy stance will impact relatively modestly on output. If rational expectations' formation plays a crucial role in price setting, the degree of policy credibility may influence the sacrifice ratio. In particular, Lucas (1972, 1973) and Sargent and Wallace (1975) emphasized the role of credibility, paving the way for the controversial concept of costless disinflation. Ball (1994b, 1994c) shows that the sacrifice ratio may even be negative given a perfectly credible disinflation. In the completely forward-looking model of Calvo (1983), credible disinflation is achieved immediately without any change/loss in output. Under rational expectations and costly price adjustments, imperfect credibility is an essential ingredient in accounting for a positive sacrifice ratio. Under adaptive expectations formation, inflation will tend to be structurally persistent. A contractive monetary policy stance will then have a smaller effect on prices and, consequently, a larger effect on output (see Ball, 1995). ${ }^{4}$

The introduction of inflation targeting may have increased the policy credibility of central banks in several ways that may have reduced the output costs of inflation stabilization. First, the introduction of inflation targeting has in practice been associated with increased transparency of policymaking, for instance due to the publication of inflation reports and minutes from policy meetings. That policy-relevant economic information has become increasingly available to the general public, may have lead to increased demand for consistency in monetary policymaking. Private agent's expectations may have become better informed and their behavior more consistent with actual policy. Second, the introduction of an

\footnotetext{
${ }^{4}$ Time series of inflation tend to be highly autocorrelated (Fuhrer and More, 1995; Piero, 2001; Driscoll and Holden, 2003). This is, however, not a sufficient condition for a high sacrifice ratio. Inflation persistence may be due to other mechanisms than expectations formation. For instance, it may be the result of policy (policy-induced persistence) where policy has been pursued to accommodate inflation, or it may merely indicate the lack of a credible nominal anchor in the economy.
} 
explicit numerical target for inflation may have made the objectives of monetary policy more concrete and comprehensible for the general public. Third, increased transparency and clearer objectives may have increased the demand for knowledge on how to stabilize inflation around the inflation target at the lowest possible costs in terms of output fluctuations. For instance, inflation targeting central banks have increased their efforts in modeling the monetary transmission mechanism, based on principles robust to the Lucas critique, by constructing models based on optimizing private agents. Finally, it is possible that the introduction of quantified inflation targets has contributed towards making inflation stabilization stricter compared to in previous times. We know that such a shift may increase welfare under discretionary policymaking by reducing the benefits of surprise increases in inflation (Rogoff, 1985). It may also reduce the output costs associated with inflation stabilization under rational expectations (see, Clarida et al., 1999). The strength of these potential mechanisms is open to debate. Note, however, that imitation among central banks and changing norms of what constitutes good monetary policy may have made the mechanisms apply to the respective countries prior to the official introduction of explicit inflation targeting.

There are beneficial effects of increased credibility on the sacrifice ratio even when inflation expectations are not fully rational. To see this, consider a simple Phillips curve model:

$$
\pi_{t}=\pi_{t+1}^{e}+\gamma x_{t}
$$

where inflation is denoted by $\pi_{t}$, inflation expectations in the next period by $\pi_{t}^{e}$, and $x_{t}$ is the output gap, i.e. the percentage deviations of output from the flexible-price level of output. Further, $(1 / \gamma)$ is a measure of the degree of nominal inertia. If $\pi_{t}^{e}=E_{t} \pi_{t+1}$, (1) represents the New-Keynesian Phillips curve ${ }^{5}$ where disinflation produces no output costs under full credibility (as discussed above). Assume, however, that credibility is less than perfect and determined outside the model. The central bank announces a reduction of the inflation target to be achieved by the end of the period. Private agents believe that inflation at the end of the period will equal the newly announced inflation target $\left(\pi_{\text {new }}^{*}\right.$ ) with probability $\alpha$ and the old inflation target $\left(\pi_{\text {old }}^{*}\right)$ with probability $(1-\alpha)$. In terms of the credibility parameter $\alpha \in[0,1]$, the expectations-augmented Phillips curve is given by

$$
\pi_{t}=\alpha \pi_{\text {new }}^{*}+(1-\alpha) \pi_{\text {old }}^{*}+\gamma x_{t}
$$

\footnotetext{
${ }^{5}$ We assume that the subjective discount factor is approximately unity.
} 
The central bank wants to stabilize inflation around the new inflation target and the output gap around zero. Assuming a quadratic loss function, the loss is given by

$$
L_{t}=\left(\pi_{t}-\pi_{\text {new }}^{*}\right)^{2}+\lambda x_{t}^{2}
$$

The first-order condition is given by

$$
x_{t}=-\left(\frac{\gamma}{\gamma^{2}+\lambda}\right)(1-\alpha)\left(\pi_{\text {old }}^{*}-\pi_{\text {new }}^{*}\right) .
$$

The percentage loss due to disinflation in period $t$ is determined by the degree of nominal inertia, the weight on the output gap in the loss function and credibility, in addition to the size of the reduction in the inflation target. The higher the credibility that the new inflation target will be achieved, the lower is the output loss. Under perfect credibility ( $\alpha=1)$, the output loss is zero. Note also that the output loss declines in the weight on output gap stabilization. By substituting (4) into (2), and expressing inflation as deviations from the new inflation target, inflation is given by

$$
\pi_{t}-\pi_{\text {new }}^{*}=(1-\alpha)\left(\frac{\lambda}{\gamma^{2}+\lambda}\right)\left(\pi_{\text {old }}^{*}-\pi_{\text {new }}^{*}\right) .
$$

We see that increased credibility immediately brings inflation towards the new inflation target, irrespective of the size of an announced reduction in the inflation target (however, increased credibility may be difficult to achieve with a highly ambitious inflation target). Importantly, the deviation from the new inflation target also depends on the weight on output gap stabilization: Strict inflation targeting $(\lambda=0)$ immediately brings inflation down to the new inflation target. Hence, if the public believes the central bank to be strict on inflation, i.e. ready to accept any output loss required to bring inflation in line with the new inflation target, inflation will immediately be brought down to that target.

A simple way of endogenizing credibility is to make it a function of the relative weight on the output gap, i.e., $\alpha=\alpha(\lambda)$, where $\alpha^{\prime}(\lambda)<0, \alpha(0)=1$. If the central bank cares only about stabilizing inflation, it will pursue the new inflation target at any costs, regardless of the loss of output. From (4) we see that the output cost of the disinflationary experiment is zero given that the private sector perceives the central bank to be strict (irrespective of its true preference). The central bank will therefore have an incentive to make the private sector believe that it is strict on inflation in order to reduce the sacrifice ratio. 
The introduction of explicit inflation targeting may be seen as an attempt to do just that. The explicit focus on inflation becomes a signal to the private sector that inflation stabilization is a high priority, and that the output cost associated with such stabilization carries less weight (i.e. that inflation stabilization is 'stricter'). Disinflation policy may then be more credible, reducing both the inflation expectations and the actual output costs to follow from such policy.

For a given degree of credibility and given preferences, equation (5) shows that the sacrifice ratio serves as an indicator of the degree of nominal inertia $\left(\frac{1}{\gamma}\right)$. In models where direct estimation of the degree of nominal inertia is cumbersome or impossible, as in VAR models, we may proxy the degree of nominal inertia indirectly through consideration of the sacrifice ratio (if one is comfortable with the assumption of unchanged monetary policy credibility).

\section{Data and empirical modeling}

The vector autoregressive (VAR) models introduced by Sims $(1970,1980)$ have been used extensively over the recent years to analyze the structure of the monetary transmission mechanism. This modeling strategy was initially developed as a reaction to the 'implausible restrictions' imposed on the dynamics of the larger Keynesian structural macroeconomic models. The analytical framework, imposing only a minimum of model restrictions, has been seen as especially fruitful for analyzing monetary policy.

The pre inflation-targeting estimation period starts in the late 1970s, and runs until the start of the inflation targeting period (1993 Q1). This is about the time that explicit inflation targeting was introduced in Canada, the United Kingdom and Sweden. The second estimation period is the same for all countries, except for Switzerland where the inflation targeting period starts in 1990 Q1. For all countries, the inflation targeting period continues till 2003 Q4. For Canada, the United Kingdom and Sweden, the pre inflation targeting period starts in 1978 Q1. ${ }^{6}$ For the remaining countries, this period starts in either 1978 Q2 (the Netherlands), 1979 Q2 (Norway), or 1981 Q2 (Switzerland). The variations in sampling periods by country are caused by restricted data availability and (for Switzerland) model stability considerations. We have applied some data points from the 1970s, although this period is often regarded as one where many countries lacked a proper nominal anchor. Under this view, observations from this decade may be seen as irrelevant for the measure of the sacrifice ratio during the 1980s

\footnotetext{
${ }^{6}$ Arguably, the inflation targeting period should start later than 1993, to allow some time for the central banks to gain credibility for their announced inflation targets. However, to start the inflation targeting period later than 1993 would have reduced the number of data points for inflation targeting, and hence the precision of the coefficient estimates.
} 
and 1990s. We include some observations from the 1970s to provide a sufficient number of data points for obtaining model stability. Table 4.1 gives the estimation periods by country.

Table 4.1 Sampling periods by country

\begin{tabular}{|l|l|l|}
\hline & Pre inflation targeting period & Inflation targeting period \\
\hline Canada & 1978 Q1 - 1992 Q4 & 1993 Q1 - 2003 Q4 \\
\hline The Netherlands & 1978 Q2 - 1992 Q4 & 1993 Q1 - 2003 Q4 \\
\hline Norway & 1979 Q2 - 1992 Q4 & 1993 Q1 - 2003 Q4 \\
\hline Sweden & 1978 Q1 - 1992 Q4 & 1993 Q1 - 2003 Q4 \\
\hline Switzerland & 1981 Q2 - 1992 Q4 & 1990 Q1 - 2003 Q4 \\
\hline The United Kingdom & 1978 Q1 - 1992 Q4 & 1993 Q1 - 2003 Q4 \\
\hline
\end{tabular}

The table shows the sampling periods for the inflation targeting and pre inflation targeting periods, respectively for all six countries. The time frame only varies somewhat for the former period, due to data availability (for the Netherlands and Norway) and model stability considerations (for Switzerland).

The endogenous variables of our VAR models are aggregate economic activity, the logarithms of the seasonally adjusted consumer price inflation $(\pi)$, the short-term nominal interest rate (i) and the change in the nominal effective exchange rate $(\Delta s)$. The time series were obtained from the OECD and IMF databases. As a measure of the output gap, we have used the Hodrick-Prescott detrended series of the logarithm of real GDP (with a standard 1600 penalty parameter for quarterly data).

In recognition of the problems of precisely measuring an unobserved variable like the output gap $\left(x=y-y^{*}\right)$ to operationalize aggregate economic activity (cf. Orphanides, 2003, and Orphanides and van Norden, 2002) we also estimate the VAR models that apply the rate of output growth $\left(d y=y-y_{-1}\right)$ as an alternative measure (both measures are seasonally adjusted). We thus estimate four VAR models for each country, two for the pre inflation targeting period and two for the subsequent inflation targeting period. Although we believe that output growth may have several advantages over the rather arbitrary output gap estimates, we still retain this measure because it seems to be the measure most relied upon by policy makers.

It could be argued that the variables selected may be too few to fully represent the monetary transmission mechanism. However, the selection of variables corresponds to those used in traditional models of the monetary transmission mechanism (see, e.g., Ball, 1999b; Svensson, 2000; Gali and Gertler, 2002) and those used to analyze monetary policy. The quite few endogenous variables also balance the intensive use of observations by VAR systems, given the 40 available quarterly data points for the inflation targeting period (1993 Q1-2003 Q4). 
The lag length of the endogenous variables was also chosen with the few observations from inflation targeting regime in mind. The likelihood ratio test, final prediction error test, Schwarz (SC), Hannan-Quinn (HQ) and Akaike information criteria (AIC) were computed for lag lengths up to six quarters for the two time periods and typically suggested the highest lag length. The UK and Canada were exceptions. For these two countries, a lag length of one or two quarters was suggested by all criteria except for the AIC, and we chose two quarters. For the other countries, we settled for a four-quarter lag length. This lag length corrects for possible seasonal patterns left in data and, furthermore, passed a Lagrange multiplier test of no autocorrelation of order six and below in the residuals at a five percent significance level.

We allow for a constant term in all equations. Further, the short-term interest rate, the rate of output growth and CPI inflation in either the United States (for Canada) or Germany (for the remaining countries) are allowed as exogenous variables. Initially all exogenous variables were included with a lag-length of four quarters. Subsequently, the lag-length for all the exogenous variables was gradually reduced until the last lag was significant at a 5 per cent level in one of the equations of the respective VAR model. The models were identified based on the ordering of the variables: $\pi, x$ or $d y, i$ and $\Delta s$. Thus, whereas the exchange rate can be influenced contemporaneously by all other endogenous variables, contemporaneous exchange rate changes can only influence the other endogenous variables with a lag. Such an identification scheme is made in accordance with the information-intensive foreign exchange market and forward-looking nature of the exchange rate. Moreover, there appears to be consensus that monetary policy influences the economy with a lag and that inflation is the slowest relevant variable to react (see, e.g., Svensson, 1997 and Christiano et al., 1999). By imposing this, economic theory-consistent, identification scheme on the data, we hope to increase the precision of our point estimates.

\subsection{Model properties}

The properties of the dynamic model may be studied through the response of a variable to a particular shock to the model. Since we focus on the effect of monetary policy on inflation, the shock to the short-term interest rate (the central banks' instrument) is of interest for the purpose of evaluating and providing a compact account of the properties of our models. ${ }^{7}$ The responses to this shock will indicate the extent to which the models generate the expected effects, in view of economic theory, to changes in monetary policy. The effects on CPI inflation and output gaps of a one standard error interest rate shock are shown in appendix B,

\footnotetext{
${ }^{7}$ Test statistics for the estimated models and the individual equations are available from the authors upon request.
} 
figure B.1 for the VAR models estimated for the inflation targeting period and figure B.2 for the pre inflation targeting period.

Overall, and as expected in view of the predictions from economic theory, there is a tendency, although weak, for the interest rate increase to reduce both the inflation rate and the output gap after some time for most countries and in both periods. This tendency is most pronounced for Canada and the UK. The result of a fall in output seems more general than the fall in inflation. This result has also been found in VAR studies of the US economy where there is a significant prize puzzle in the data - so that inflation tends to rise temporarily after the monetary policy shock (see, e.g., Hanson, 2004). A possible explanation for this puzzle may be the rise in costs associated with the financing of the firm following an interest rate increase (see Ravenna and Walsh, 2003).

While the effects of the interest rate on inflation and output are much less clear than in the theoretical models (e.g., Svensson, 2000 and Ball, 1999b), they still fit reasonably well with the results from the theory models compared to the results from other small open-economy VAR studies. For instance, Dedola and Lippi (2000) report that prices in the United Kingdom tend to increase after a shock to the interest rate, but fall below the initial level after about two years. They find an even stronger price puzzle in models for Italy, Germany and France, where prices seem to increase both in the short and the long run after a shock to the interest rate. Similarly, Bagliano et al. (1999) find that prices in Germany are expected to rise in the long run after a positive shock to the interest rate, and Hubrich and Vlaar (2004) report that German inflation only falls in the first quarter after a contractionary monetary policy shock. However, Cushman and Zha's (1997) VAR study of the Canadian economy finds broader support for the theoretical proposition that prices falls after a monetary policy shock.

In conclusion, although the effects of the interest rate shock in our VAR models may deviate from the theoretical predictions, the properties of our empirical models do not appear more puzzling than what is common in other VAR studies, where, in the words of Jacobsson et al. (2002, p. 3), “... it seems hard to get empirical support even for the very reasonable idea that a contractionary monetary policy shock leads to lower inflation.” The current paper suffers from some of the same weaknesses as other VAR studies, though in our view, not seriously. 


\section{The policy experiment of disinflation}

In this section we estimate the sacrifice ratios for Canada, Norway, the Netherlands, Sweden, Switzerland and the United Kingdom through simulation of the estimated VAR models. We assume that the economy is in equilibrium at the start of the disinflation period, as is common in other empirical approaches to the sacrifice ratio. The monetary authority then wishes to reduce the inflation rate by one percentage point, to a level equal to the historical average rate of inflation. If the common assumption of long-run superneutrality of money holds, i.e. that monetary policy - in particular the choice of steady-state level of inflation - has no real effect in the long run, the historical average rate of inflation will work as well as any other inflation level as the new inflation target. ${ }^{8}$ Finally, we assume that the monetary policymaker uses the historical (identified) strategy in the particular sample period to reduce inflation. Thus, we assume that the central bank enjoys the same credibility for the new inflation target as the old one. Since policy is as in earlier periods, we would expect no change in the parameters of the VAR models. While this does in isolation make the analysis less vulnerable to the Lucas critique, it also implies an assumption that the central bank is able to retain its credibility for the choice of any inflation target.

Since the variables are modeled as deviations from their respective historical averages by the inclusion of constant terms in the VAR model, an experiment of a change in the inflation target (the unconditional expectations of inflation) can be designed by shocking the state variables that are expected to have their unconditional expectations changed as a result of the experiment. Under the assumption of long-run monetary neutrality, the Fisher equation and the relative purchasing power parity condition suggest that both the unconditional expectations of the nominal interest rate and the change in the nominal effective exchange rate are affected by the change in the unconditional expectations of inflation. The unconditional expectations of the nominal interest rate are related to the unconditional quarterly inflation expectations through the Fisher equation, i.e.

$$
E i_{t}=E r_{t}+4 E \pi_{t}=E r_{t}+\pi^{*}
$$

where the operator $E$ denotes unconditional expectations and we have used that the unconditional expectations are equal to the target for annual inflation $\left(\pi^{*}\right)$. Due to the

\footnotetext{
${ }^{8}$ We acknowledge that the inflation level may influence real wage flexibility. The choice of inflation target may indeed matter in the long run for very low inflation targets, i.e. the arguments offered by Tobin (1972) and Akerlof et al. (2000); see also the literature review in Palenzuela et al. (2003). From our reading of the literature, however, the observed average inflation rates for our sample countries over the last 25 years do not seem problematic as they are above the rates at which we would believe inflation not to give sufficient flexibility to real wages. We therefore believe the assumption of longrun superneutrality of money to be relatively harmless in our case.
} 
assumption of long-run monetary neutrality, $E r_{t}$ is unaffected by the experiment and there is a one-to-one relationship between the unconditional expectations of nominal interest rates and inflation. Moreover, the change in the unconditional nominal effective exchange rate is given by

$$
E \Delta s_{t}=E \pi_{t}^{f}-E \pi_{t}=E \pi_{t}^{f}-\pi_{t}^{*},
$$

where $\pi^{f}$ is the foreign inflation rate. A decrease in the inflation target, implies a fall in unconditional expected nominal interest rate and that the unconditional expected rate of appreciation will increase, according to equations (7) and (8). Under the assumption that the economies are in equilibrium and state variables are equal to their old unconditional expectations (normalized to zero through the inclusion of the constant terms in the VAR model), the disinflationary experiment implies that the nominal interest rates and the inflation rate increases (relative to the new unconditional expectations) and the rate of appreciation decreases similarly. For a decrease of the annual inflation rate of one percentage point, the disinflationary experiment is constructed by shocking the initial and lagged values of state variables as $i_{t-j}=0.01, \pi_{t-j}=0.0025$ and $\Delta s=-0.0025$ for $j=0, \ldots, L$ where $L$ is the number of lags in the VAR model. We then measure the loss of output by simulating the model with these initial conditions in accordance with equation (1) by discounting at three per cent annually - as figure commonly used to approximate the equilibrium real interest rate. We carried out 10000 successful repetitions of this experiment, each time drawing a different set of coefficients from the estimated distribution of each coefficient and simulating the model. The estimates based on the output gap and those based on output growth largely point in the same direction. The output gap measure may be controversial (see the discussion above), but is still the most commonly used measure of aggregate economic activity relied upon by policy makers. We report estimates based on both measures in tables 5.1 and 5.2. 
Table 5.1 Sacrifice ratio estimates with economic activity operationalized as the output gap

\begin{tabular}{|c|c|c|}
\hline Sacrifice ratio estimates (mean, per cent) & Pre IT period & IT period \\
\hline \multicolumn{3}{|l|}{ Explicit inflation targeting countries } \\
\hline Canada & $\begin{array}{c}2.47 \\
(5.30)\end{array}$ & $\begin{array}{c}\mathbf{0 . 0 6} \\
(4.64)\end{array}$ \\
\hline Sweden & $\begin{array}{c}0.11 \\
(6.22)\end{array}$ & $\begin{array}{l}-0.29 \\
(9.33)\end{array}$ \\
\hline The United Kingdom & $\begin{array}{c}0.54 \\
(2.76)\end{array}$ & $\begin{array}{c}0.63 \\
(5.34)\end{array}$ \\
\hline \multicolumn{3}{|l|}{ Countries without explicit inflation targets } \\
\hline Norway & $\begin{array}{c}1.17 \\
(6.88)\end{array}$ & $\begin{array}{c}-1.41 \\
(3.37)\end{array}$ \\
\hline Switzerland & $\begin{array}{c}-0.80 \\
(10.38)\end{array}$ & $\begin{array}{c}-0.31 \\
(14.78)\end{array}$ \\
\hline The Netherlands & $\begin{array}{l}-0.75 \\
(6.79)\end{array}$ & $\begin{array}{l}-1.33 \\
(8.30)\end{array}$ \\
\hline
\end{tabular}

The sacrifice ratio is calculated as the cumulated output loss during the disinflation period, see equation (1). The table shows the mean estimated sacrifice ratios for the individual countries of the sample through Monte Carlo simulation of estimated VARs with 10000 replications, drawing each time a new set of coefficients in accordance with their estimated distribution. Draws that implied either an explosive model or an absolute value of the sacrifice ratio in excess of 100 per cent were disregarded. Point estimates for both the pre IT and the IT period are reported, with standard errors in parentheses.

Table 5.2 Sacrifice ratio estimates with economic activity operationalized as output growth

\begin{tabular}{|c|c|c|}
\hline Sacrifice ratio estimates (mean, per cent) & Pre IT period & IT period \\
\hline \multicolumn{3}{|l|}{ Explicit inflation targeting countries } \\
\hline Canada & $\begin{array}{c}1.63 \\
(1.87)\end{array}$ & $\begin{array}{c}-\mathbf{0 . 5 2} \\
(2.86)\end{array}$ \\
\hline Sweden & $\begin{array}{l}-0.07 \\
(0.32)\end{array}$ & $\begin{array}{l}-0.07 \\
(4.42)\end{array}$ \\
\hline United Kingdom & $\begin{array}{c}0.26 \\
(1.00) \\
\end{array}$ & $\begin{array}{c}-0.17 \\
(2.45) \\
\end{array}$ \\
\hline \multicolumn{3}{|l|}{ Countries without explicit inflation targets } \\
\hline Norway & $\begin{array}{c}\mathbf{0 . 5 3} \\
(4.18)\end{array}$ & $\begin{array}{c}\mathbf{0 . 0 3} \\
(4.64)\end{array}$ \\
\hline Switzerland & $\begin{array}{c}-0.03 \\
(4.81)\end{array}$ & $\begin{array}{c}0.02 \\
(7.12)\end{array}$ \\
\hline The Netherlands & $\begin{array}{c}0.00 \\
(4.32)\end{array}$ & $\begin{array}{c}1.79 \\
(6.25)\end{array}$ \\
\hline
\end{tabular}

See note for table 5.1.

At least two observations from this experiment seem important for our purpose: First, the sacrifice ratio declines for most countries during the inflation targeting period. This tendency is most marked for Canada and Norway, which experienced relatively high sacrifice ratios in the first period. Numerous devaluations in Norway during the 1980s and early 1990s may, at least in part, explain the high sacrifice ratio due to a lack of a credible nominal anchor in this period. Norwegian monetary policy may have been more successful in the post 1993 period, when the operational exchange-rate target was switched from a fixed but adjustable to a stable exchange rate. Although larger short-term variations were allowed, the new regime appeared 
more robust to currency speculation and thus more credible. ${ }^{9}$ Switzerland, which experienced a relatively low sacrifice ratio in the first period, did, however, see a rise in the sacrifice ratio. For the Netherlands, it is difficult to draw conclusions on the evolvement of the sacrifice ratio over time as estimates based on the output gap and output growth point in different directions.

Second, and perhaps the more interesting for our study, is the common drop over time in the sacrifice ratio estimates for the inflation targeting countries. Only the output gap-based sacrifice ratio estimate for the UK indicates a very small increase; all the other estimates show a decrease in the sacrifice ratio. ${ }^{10}$ Among the countries that did not explicitly target the inflation rate, the results are more diverse. We interpret this as some, although weak evidence that explicit inflation targeting increases the credibility of inflation targets of the central banks.

One should keep in mind, however, that most of the sacrifice ratios are imprecisely estimated. The associated uncertainty is partly a result of the high number of coefficients to be estimated in the applied VAR models. The uncertainty is also in part due to the use of only a minimum of exclusion restrictions from economic theory in the models. Thus, we pay a price for theory independence in terms of quite imprecise point estimates. We note, however, that the degree of uncertainty is small in our study compared to other similar applications of VAR models (cf. Cecchetti and Rich, 1999, 2001).

\subsection{Comparing our results with sacrifice ratio estimates from other studies}

Ball (1994a), Jordan (1997) and Corbo et al. (2001) have estimated sacrifice ratios for the countries in our sample, and Johnson and Gerlich (2002) have estimated sacrifice ratios for Canada. The results of these studies are summarized in table 5.3.

\footnotetext{
${ }^{9}$ Increased credibility was also linked to a clause in the exchange rate regulation, specifying that in the event of fluctuations outside the preferred exchange rate range, monetary policy would over time be pursued with a view to bringing the exchange rate back inside the preferred band.

${ }^{10}$ The reduction in the sacrifice ratio based on output growth for Sweden is however small and appears at the third decimal point.
} 
Table 5.3 Estimates by other authors of sacrifice ratios for our sample countries

\begin{tabular}{|l|c|c|c|c|c|c|c|}
\hline Source: & Canada & Norway & $\begin{array}{c}\text { The } \\
\text { Netherlands }\end{array}$ & Sweden & Switzerland & $\begin{array}{c}\text { The } \\
\text { U.K. }\end{array}$ & Avg. \\
\hline Jordan (1997) & 3.62 & -0.64 & 6.14 & 2.44 & 2.87 & 1.31 & 2.62 \\
Ball (1994a) & 1.70 & n.a. & 0.18 & 0.44 & 1.65 & 0.68 & 0.93 \\
$\begin{array}{l}\text { Corbo et al. } \\
\text { (2001) }\end{array}$ & n.a. & -0.87 & 1.47 & 0.60 & 0.87 & 0.90 & 0.59 \\
Johnson and & $1.47^{\dagger}$ & - & - & - & - & - & - \\
$\begin{array}{l}\text { Gerlich (2002) } \\
\text { Average }\end{array}$ & 2.26 & -0.76 & 2.60 & 1.16 & 1.80 & 0.96 & 1.39 \\
\hline
\end{tabular}

The table shows the various authors' sacrifice ratio estimates for the countries in our sample. The figures from Ball (1994a) are time-weighted estimates from disinflation periods. Jordan (1997) divides his sample into episodes of disinflation and reflation and reports a different sacrifice ratio for each episode. The figures here are time-weighted averages of both types of episodes. Corbo et al. report one sacrifice ratio for each country estimated through a 5-dimensional VAR. The associated standard errors are not available (not calculated and/or not reported). For further details, see appendix A. †: Johnson and Gerlich (2002) report a number of estimates of the sacrifice ratio in Canada. The Bank of Canada's (1999) estimate is 2.27. The estimate used here relies on a HP filter as a measure of potential output. Other measures of potential output, e.g. cubic and quadratic trend yield much larger figures - approximately 4 and 8-9, respectively.

The studies provide estimates of the sacrifice ratio that are of the same order of magnitude as ours. The Jordan study's estimates are higher than ours, although not significantly so. ${ }^{11}$ Moreover, the sacrifice ratio for Canada is larger than the average, corresponding with our results for the pre inflation targeting period (but not the inflation targeting period).

Comparing the estimates of the Jordan (1997) study with those of the later Corbo et al. (2001) and Johnson and Gerlich (2002) studies, there is a fall in the sacrifice ratio for all countries considered, supporting our result of decreased sacrifice ratios over time. The earliest study of Ball (1994a) does, however, not support this proposition as it generally suggests a smaller sacrifice ratio for the period prior to the 1990s. Note, however, that our estimates for the pre inflation targeting period, and particularly those where output growth measure aggregate economic activity, are closer to those of Ball (1994a) than those of Jordan (1997).

\section{Concluding remarks}

In this paper, we have estimated sacrifice ratios for Canada, Norway, the Netherlands, Sweden, Switzerland and the United Kingdom. For this purpose, we use a methodology based on simulation of estimated VAR models in which the historical monetary policy is identified. The sacrifice ratio is estimated under the historically identified policy, with given central bank credibility and reaction functions. Our methodology makes the sacrifice ratio reflect the cost of deliberate disinflation policy in contrast to, e.g., the output cost of a series of negative cost-push shocks. We compare estimates of the sacrifice ratio for two time periods, prior and

\footnotetext{
${ }^{11}$ One likely reason for this is that the Jordan study involves information from the 1970s that was a period of very little credibility for inflation stabilization credibility at many central banks.
} 
subsequent to the introduction of inflation targeting in three of the sample countries in the early 1990s.

The sacrifice ratio appears to have declined for the inflation-targeting countries. This result is robust to the operationalization of aggregate economic activity as either the output gap (detrended output) or real output growth in the VAR model (albeit the UK output-gap based sacrifice ratio estimate suggests a small increase). There is no such consistent pattern for the countries that did not introduce explicit inflation targeting. Although the sacrifice ratio seems to have fallen considerably over time for Norway, the development for the Netherlands and Switzerland depends on choice of variable for aggregate economic activity in the VAR models. Keeping in mind that the sample of countries is small and the time series quite short, we nevertheless interpret our findings as supportive of a credibility-enhancing effect of explicit inflation targeting. As the time span of inflation targeting lengthens and more data become available, future research will be able to investigate the degree of robustness of our finding. 


\section{References}

Akerlof, G., W. Dickens and G. Perry. 2000. "Near-rational wage and price setting and the long-run Phillips curve”, Brookings Papers on Economic Activity 1, 1-60.

Bagliano, F., C. Favero, and F. Franco. 1999. "Measuring monetary policy in open economies”, CEPR discussion paper no. 2079.

Ball, L. 1994a. "What determines the sacrifice ratio”. In Mankiw, N. (ed.), Monetary policy, Chicago: University of Chicago Press, 155-182.

. 1994b. "Credible disinflation with staggered price-setting”, American Economic

Review 84, 282-289.

$5-23$.

1994c. “Disinflation with imperfect credibility”, Journal of Monetary Economics 35,

. 1995. "The genesis of inflation and the costs of disinflation”, Journal of Money,

Credit, and Banking 23, 439-452.

. 1999a. "Efficient rules for monetary policy”, International Finance 2, 63-83.

. 1999b. "Policy rules for open economies”. In Taylor, J. (ed.), Monetary policy rules, NBER Conference Report Series, Chicago and London: Chicago University Press.

, and D. Romer (1990). "Real rigidities and the non-neutrality of money”, Review of

Economic Studies 57, 183-203.

Baltensperger, E. and P. Kugler. 2000. "Central bank independence and sacrifice ratios: some further considerations”, Open Economies Review 11, 111-125.

Bank of Canada. 1999. Monetary policy report, November.

Bernanke, B., T. Laubach, F. Mishkin and A. Posen. 1999. Inflation targeting: Lessons from the international experience, Princeton, New Jersey: Princeton University Press.

Blanchard, O. 1983. "Price asynchronization and price level inertia”. In Inflation, debt and indexation, R. Dornbusch and M. Simonsen (eds.), 3-24, Cambridge, Massachussets: MIT Press.

Calvo, G. 1983. “Staggered prices in a utility-maximizing framework”. Journal of Monetary Economics 12, 383-398.

Cecchetti, S. 1994. Comment to L. Ball "What determines the sacrifice ratio". In Mankiw, N. (ed.), Monetary policy, Chicago: University of Chicago Press, 188-193.

and R. Rich. 1999. "Structural estimates of the U.S. sacrifice ratio", mimeo, Federal Reserve Bank of New York (the working paper version of Cecchetti and Rich, 2001). . 2001. "Structural estimates of the U.S. sacrifice ratio", Journal of Business and Economic Statistics 19, 416-427. 
Christiano, L, M. Eichenbaum and C. Evans. 1999. "Monetary policy shocks: What have we learned and to what end?”, in Taylor and Woodford (eds.), Handbook of Macroeconomics, Vol 1A, Amsterdam: Elsevier.

Clarida, R., J. Gali and M. Gertler (1999), "The science of monetary policy: A New Keynesian perspective,” Journal of Economic Literature 37, 1661-1707.

Corbo, V, O. Moreno, and K. Schmidt-Hebbel. 2001. "Assessing inflation targeting after a decade of world experience”, mimeo, Central Bank of Chile.

Cushman, D. and T. Zha. 1997. "Identifying monetary policy in a small open economy under flexible exchange rates”, Journal of Monetary Economics 39, 433-448.

Dedola, L. and F. Lippi. 2001. "The monetary transmission mechanism: Evidence from the industries of five OECD countries”, CEPR discussion paper no. 2508.

Friedman, B. 1994. Comment to L. Ball "What determines the sacrifice ratio". In Mankiw, N. (ed.), Monetary policy, Chicago: University of Chicago Press, 182-188.

Fuhrer, J. and G. Moore. 1995. “Inflation persistence”, Quarterly Journal of Economics 110, 127-159.

Gordon, R. 1982. "The output cost of disinflation in traditional and vector autoregressive models,” Brookings Papers on Economic Activity 1, 205-242.

Hanson, M. S. (2004), “The “price puzzle” reconsidered,” Journal of Monetary Economics, $51,1385-1413$.

Hubrich, K. and P. Vlaar. 2004. "Monetary transmission in Germany: Lessons for the Euro area”, Empirical Economics 29(2), 383-414.

Jacobsson, T, P. Jansson, A. Vredin, and A. Warne. 2002. "Identifying the effects of monetary policy shocks in an open economy”, Working paper no. 134 Sveriges Riksbank.

Johnson, D. and S. Gerlich. 2002. "How has inflation changed in Canada?” Canadian Public Policy 28, 563-579.

Jordan, T.1997.”'Disinflation costs, accelerating inflation gains, and central bank independence", Weltwirtschaftliches Archiv/Review of World Economics 133, 1-19.

Lucas, R. 1972. "Expectations and the neutrality of money”, Journal of Economic Theory 4, 103-124.

Lucas, R. 1973. "Some international evidence on output-inflation trade-offs”, American Economic Review 63, 326-344.

Okun, A. 1978. “Efficient disinflationary policies”, American Economic Review 68, 348-352.

Orphanides, A. and S. van Norden. 2002. "The unreliability of output-gap estimates in real time", Review of Economics and Statistics 84, 569-583.

Orphanides, A. 2003. “The quest for prosperity without inflation”, Journal of Monetary Economics 50, 633-663. 
Palenzula, D., G. Camba-Méndez, and J. García. 2003. "Relevant economic issues concerning the optimal rate of inflation”, Working paper no. 278, the European Central Bank: Frankfurt.

Piero, G. 2001. "Backward-looking indexation, credibility and inflation persistence”, Journal of International Economics 53, 127-147.

Ravenna, F., and C. Walsh (2003), “The cost channel in a New Keynesian model: Evidence and implications”, mimeo, University of California, Santa Cruz.

Rogoff, K. (1985), “The Optimal Commitment to an Intermediate Monetary Target," Quarterly Journal of Economics 100, 1169-1189.

Sargent, T. 1982. “The end of four big inflations”. In Hall, R. (ed.), Inflation: Causes and Effects, Chicago: Chicago University Press.

and N. Wallace. 1975. "Rational expectations, the optimal monetary instrument, and the optimal money supply rule”, Journal of Political Economy 83, 241-254.

Svensson, L. 1997. "Inflation forecast targeting: Implementing and monitoring inflation targets”, European Economic Review 41, 1111-1146.

$50,155-183$.

2000. “Open-economy inflation targeting”, Journal of International Economics

Taylor, J. 1979. "Staggered wage setting in a macro model”, American Economic Review 69, 108-113.

Tobin, J.1972. "Inflation and unemployment”, American Economic Review 85, 150-167. 


\section{Appendix A. Some previous estimates of sacrifice ratios}

Table A.1 Estimates of the sacrifice ratio (sacrifice ratio) for our sample countries

\begin{tabular}{|c|c|c|c|c|}
\hline Study & Country & Method & Sample period & sacrifice ratio \\
\hline Ball (1994a) & Canada & Disinflation episodes & $\begin{array}{l}74: 2-76: 4,81: 2 \\
-85: 2\end{array}$ & 1.70 \\
\hline Jordan (1997) & Canada & Disinflation episodes & $74-76,81-85$ & 1.98 \\
\hline Jordan (1997) & Canada & Reflation episodes & $\begin{array}{l}62-74,76-81 \\
85-90\end{array}$ & 4.17 \\
\hline $\begin{array}{l}\text { Corbo et al. } \\
\text { (2001) }\end{array}$ & Norway & Struct. VAR(5) & $80-99$ & -0.87 \\
\hline Jordan (1997) & Norway & Disinflation episodes & $\begin{array}{l}64-68,75-78 \\
81-85\end{array}$ & -2.04 \\
\hline Jordan (1997) & Norway & Reflation episodes & $\begin{array}{l}68-75,78-81 \\
85-87\end{array}$ & 0.66 \\
\hline Ball (1994a) & Netherlands & Disinflation episodes & $\begin{array}{l}65-67,75-78 \\
81-83,84-86\end{array}$ & 0.18 \\
\hline $\begin{array}{l}\text { Corbo et al. } \\
\text { (2001) }\end{array}$ & Netherlands & Struct. VAR(5) & $80-99$ & 1.47 \\
\hline Jordan (1997) & Netherlands & Disinflation episodes & $\begin{array}{l}65-67,75-78 \\
80-86\end{array}$ & 6.95 \\
\hline Jordan (1997) & Netherlands & Reflation episodes & $\begin{array}{l}61-65,67-75 \\
78-80,86-91\end{array}$ & 5.65 \\
\hline Ball (1994a) & Sweden & Disinflation episodes & $\begin{array}{l}65-68,77-78 \\
80-82,83-86\end{array}$ & 0.44 \\
\hline $\begin{array}{l}\text { Corbo et al. } \\
\text { (2001) }\end{array}$ & Sweden & Struct. VAR(5) & $80-99$ & 0.60 \\
\hline Jordan (1997) & Sweden & Disinflation episodes & $\begin{array}{l}66-68,76-78 \\
80-86\end{array}$ & 1.99 \\
\hline Jordan (1997) & Sweden & Reflation episodes & $\begin{array}{l}63-66,68-76 \\
78-80,86-90\end{array}$ & 2.72 \\
\hline Ball (1994a) & Switzerland & Disinflation episodes & $\begin{array}{l}73: 4-77: 4,81: 3 \\
-83: 4\end{array}$ & 1.65 \\
\hline $\begin{array}{l}\text { Corbo et al. } \\
(2001)\end{array}$ & Switzerland & Struct. VAR(5) & $80-99$ & 0.87 \\
\hline Jordan (1997) & Switzerland & Disinflation episodes & $\begin{array}{l}66-68,74-77 \\
81-86\end{array}$ & 3.28 \\
\hline Jordan (1997) & Switzerland & Reflation episodes & $\begin{array}{l}68-74,77-81 \\
86-90\end{array}$ & 2.55 \\
\hline Ball (1994a) & U.K. & Disinflation episodes & $\begin{array}{l}61: 2-63: 3,65: 2 \\
-66: 3,75: 1- \\
78: 2,80: 2-83: 3 \\
84: 2-86: 3\end{array}$ & 0.68 \\
\hline $\begin{array}{l}\text { Corbo et al. } \\
\text { (2001) }\end{array}$ & U. K. & Struct. VAR(5) & $80-99$ & 0.90 \\
\hline Jordan (1997) & U.K. & Disinflation episodes & $\begin{array}{l}61-63,75-78 \\
80-83,84-86\end{array}$ & -0.21 \\
\hline Jordan (1997) & U.K. & Reflation episodes & $\begin{array}{l}63-75,78-80 \\
83-84,86-89\end{array}$ & 2.28 \\
\hline
\end{tabular}




\section{Appendix B. Impulse-response functions}

\section{Figure B.1. The inflation targeting period}

Response of inflation and the output (gap) to a one-standard-deviation shock to the interest rate. Results from estimated VAR models are shown, with aggregate economic activity operationalized both as detrended output (output gap) and output growth and bands of \pm 2 standard errors.

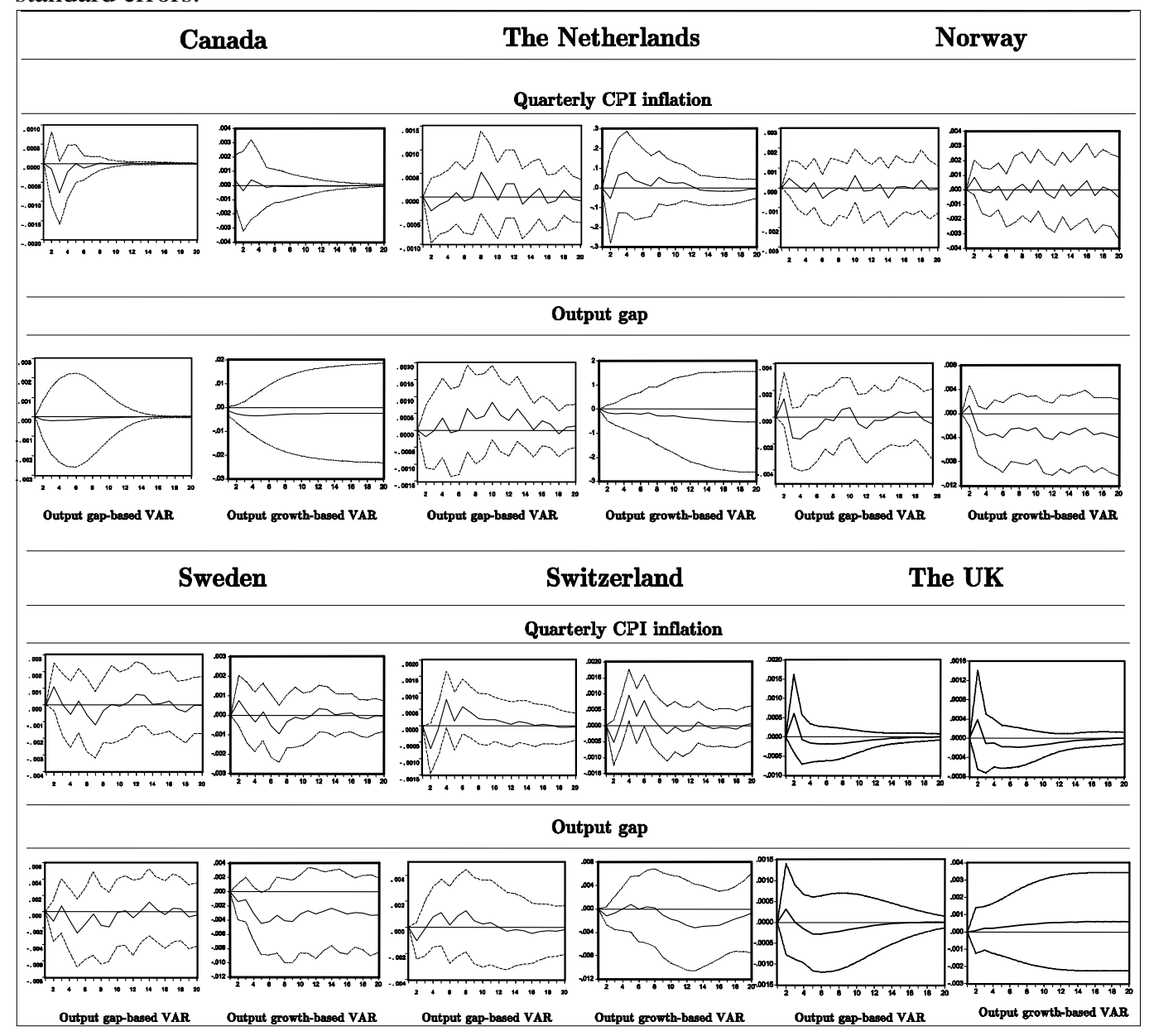


Figure B.2. The pre inflation targeting period

Response of inflation and the output (gap) to a one-standard-deviation shock to the interest rate. Results from estimated VAR models are shown, with aggregate economic activity operationalized both as detrended output (output gap) and output growth and bands of \pm 2 standard errors.

Canada Nhe Netherlands
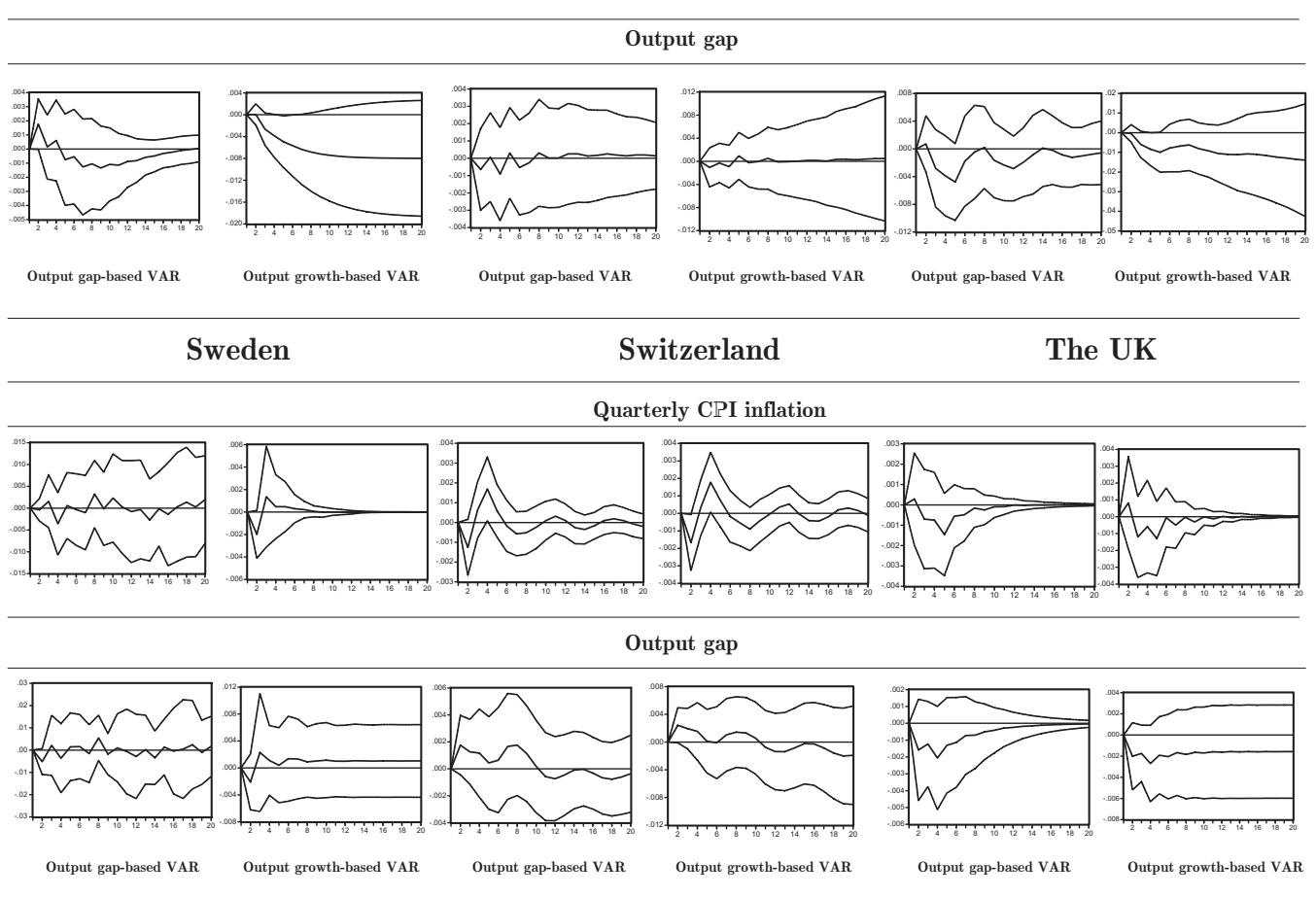


\title{
Measuring the sacrifice ratio Some international evidence
}

\author{
TEST STATISTICS \\ (not intended for publication) \\ Kai Leitemo \\ Norwegian School of Management (BI) \\ and \\ Ole Bjørn Røste* \\ Norwegian University of Science and Technology \\ March 2005
}

\begin{abstract}
We give an account of the test statistics associated with the estimation of the VAR models in Leitemo and Røste (2005).
\end{abstract}

\footnotetext{
- Complete estimation results are available at http://www.economics.no/LRVARest.pdf.
} 


\section{Canada}

a) Inflation targeting, Y: Output gap

Sample: 1993Q1 2003Q4. Included observations: 44. Standard errors in ( ).

\section{Equation test statistics}

\begin{tabular}{lcccc} 
& Eq 1 (LNP_SA) & Eq 2 (DLNY_SA) & Eq 3 (I) & Eq 4 (DLNS) \\
R-squared & 0.488269 & 0.928858 & 0.894164 & 0.347948 \\
Adj. R-squared & 0.241227 & 0.894514 & 0.843071 & 0.033164 \\
Sum sq. resids & 0.000443 & 0.000334 & 0.000818 & 0.022341 \\
S.E. equation & 0.003910 & 0.003393 & 0.005310 & 0.027756 \\
F-statistic & 1.976460 & 27.04540 & 17.50061 & 1.105355 \\
Log likelihood & 190.6818 & 196.9205 & 177.2188 & 104.4483 \\
Akaike AIC & -7.985535 & -8.269112 & -7.373580 & -4.065831 \\
Schwarz SC & -7.377289 & -7.660866 & -6.765334 & -3.457585 \\
Mean dependent & 0.004530 & 0.000112 & 0.044373 & -0.000596 \\
S.D. dependent & 0.004489 & 0.010448 & 0.013404 & 0.028228 \\
\multicolumn{5}{l}{ Determinant resid covariance (dof adj.) } \\
Determinant resid covariance & $2.86 \mathrm{E}-18$ & & \\
Log likelihood & $5.40 \mathrm{E}-19$ & & \\
Akaike information criterion & 675.6598 & & \\
Schwarz criterion & -27.98454 & &
\end{tabular}

b) Pre inflation targeting, $Y$ : Output gap

Sample: 1978Q1 1992Q4. Included observations: 60. Standard errors in ( ) \& t-statistics in [ ].

\begin{tabular}{lcccc}
\multicolumn{5}{c}{ Equation test statistics } \\
& Eq 1 (LNP_SA) & Eq 2 (DLNY_SA) & Eq 3 (I) & Eq 4 (DLNS) \\
R-squared & 0.834015 & 0.929712 & 0.904527 & 0.308520 \\
Adj. R-squared & 0.766831 & 0.901262 & 0.865883 & 0.028635 \\
Sum sq. resids & 0.000631 & 0.001437 & 0.005617 & 0.018104 \\
S.E. equation & 0.003875 & 0.005850 & 0.011564 & 0.020762 \\
F-statistic & 12.41386 & 32.67893 & 23.40673 & 1.102309 \\
Log likelihood & 258.7510 & 234.0429 & 193.1545 & 158.0427 \\
Akaike AIC & -8.025032 & -7.201430 & -5.838482 & -4.668089 \\
Schwarz SC & -7.396729 & -6.573127 & -5.210179 & -4.039786 \\
Mean dependent & 0.014846 & 0.000690 & 0.107710 & -0.002937 \\
S.D. dependent & 0.008026 & 0.018617 & 0.031577 & 0.021065 \\
\multicolumn{5}{l}{ Model test statistics } \\
Determinant resid covariance (dof adj.) & $2.73 \mathrm{E}-17$ & & \\
Determinant resid covariance & $6.55 \mathrm{E}-18$ & & \\
Log likelihood & 846.4727 & & \\
Akaike information criterion & -25.81576 & & \\
Schwarz criterion & -23.30254 & &
\end{tabular}


c) Inflation targeting period, Y: Output growth

Sample: 1993Q1 2003Q4. Included observations: 44. Standard errors in ( ) \& t-statistics in [ ].

\begin{tabular}{|c|c|c|c|c|}
\hline & \multicolumn{4}{|c|}{ Equation test statistics } \\
\hline & Eq 1 (LNP_SA) & Eq 2 (DLNY_SA) & Eq $3(I)$ & Eq 4 (DLNS) \\
\hline R-squared & 0.486058 & 0.728954 & 0.862743 & 0.353048 \\
\hline Adj. R-squared & 0.237949 & 0.598103 & 0.796481 & 0.040726 \\
\hline Sum sq. resids & 0.000445 & 0.000299 & 0.001060 & 0.022166 \\
\hline S.E. equation & 0.003919 & 0.003209 & 0.006047 & 0.027647 \\
\hline F-statistic & 1.959046 & 5.570908 & 13.02020 & 1.130396 \\
\hline Log likelihood & 190.5869 & 199.3706 & 171.4996 & 104.6210 \\
\hline Akaike AIC & -7.981224 & -8.380480 & -7.113619 & -4.073683 \\
\hline Schwarz SC & -7.372978 & -7.772234 & -6.505373 & -3.465436 \\
\hline Mean dependent & 0.004530 & 0.008512 & 0.044373 & -0.000596 \\
\hline S.D. dependent & 0.004489 & 0.005063 & 0.013404 & 0.028228 \\
\hline \multicolumn{5}{|c|}{ Model test statistics } \\
\hline \multicolumn{2}{|c|}{ Determinant resid covariance (dof adj.) } & $3.75 E-18$ & & \\
\hline \multicolumn{2}{|c|}{ Determinant resid covariance } & 7.07E-19 & & \\
\hline \multicolumn{2}{|l|}{ Log likelihood } & 669.7193 & & \\
\hline \multicolumn{2}{|c|}{ Akaike information criterion } & -27.71451 & & \\
\hline \multicolumn{2}{|l|}{ Schwarz criterion } & -25.28153 & & \\
\hline
\end{tabular}

d) Pre inflation targeting period, Y: Output growth

Sample: 1978Q1 1992Q4. Included observations: 60. Standard errors in ( ) \& t-statistics in [ ].

\begin{tabular}{|c|c|c|c|c|}
\hline & \multicolumn{4}{|c|}{ Equation test statistics } \\
\hline & Eq 1 (LNP_SA) & Eq 2 (DLNY_SA) & Eq $3(\mathrm{I})$ & Eq 4 (DLNS) \\
\hline R-squared & 0.830066 & 0.659186 & 0.887579 & 0.324211 \\
\hline Adj. R-squared & 0.761283 & 0.521237 & 0.842075 & 0.050677 \\
\hline Sum sq. resids & 0.000646 & 0.001673 & 0.006614 & 0.017693 \\
\hline S.E. equation & 0.003921 & 0.006311 & 0.012549 & 0.020525 \\
\hline F-statistic & 12.06794 & 4.778493 & 19.50566 & 1.185268 \\
\hline Log likelihood & 258.0455 & 229.4892 & 188.2523 & 158.7313 \\
\hline Akaike AIC & -8.001518 & -7.049641 & -5.675078 & -4.691043 \\
\hline Schwarz SC & -7.373215 & -6.421338 & -5.046774 & -4.062739 \\
\hline Mean dependent & 0.014846 & 0.005874 & 0.107710 & -0.002937 \\
\hline S.D. dependent & 0.008026 & 0.009121 & 0.031577 & 0.021065 \\
\hline \multicolumn{5}{|c|}{ Model test statistics } \\
\hline \multicolumn{2}{|c|}{ Determinant resid covariance (dof adj.) } & $3.52 \mathrm{E}-17$ & & \\
\hline \multicolumn{2}{|c|}{ Determinant resid covariance } & 8.46E-18 & & \\
\hline \multicolumn{2}{|c|}{ Log likelihood } & 838.7980 & & \\
\hline \multicolumn{2}{|c|}{ Akaike information criterion } & -25.55993 & & \\
\hline \multicolumn{2}{|l|}{ Schwarz criterion } & -23.04672 & & \\
\hline
\end{tabular}




\section{The Netherlands}

a) Inflation targeting, Y: Output gap

Sample: 1993Q1 2003Q4. Included observations: 44. Standard errors in ( ) \& t-statistics in [ ].

Equation test statistics

\begin{tabular}{lcccc} 
& Eq 1 (LNP_SA) & Eq 2 (DLNY_SA) & Eq 3 (I) & Eq 4 (DLNS) \\
R-squared & 0.605681 & 0.951018 & 0.952820 & 0.818843 \\
Adj. R-squared & 0.058015 & 0.882987 & 0.887293 & 0.567236 \\
Sum sq. resids & 0.000123 & 0.000216 & 0.000364 & 0.001418 \\
S.E. equation & 0.002616 & 0.003462 & 0.004500 & 0.008874 \\
F-statistic & 1.105931 & 13.97922 & 14.54079 & 3.254456 \\
Log likelihood & 218.8670 & 206.5278 & 194.9932 & 165.1127 \\
Akaike AlC & -8.766680 & -8.205808 & -7.681508 & -6.323305 \\
Schwarz SC & -7.712387 & -7.151514 & -6.627214 & -5.269011 \\
Mean dependent & 0.006333 & -0.001265 & 0.044373 & -0.001243 \\
S.D. dependent & 0.002695 & 0.010121 & 0.013404 & 0.013490 \\
\multicolumn{5}{l}{ Determinant resid covariance (dof adj.) } \\
Determinant resid covariance & $6.40 \mathrm{E}-20$ & & \\
Log likelihood & $1.79 \mathrm{E}-21$ & & \\
Akaike information criterion & 801.2152 & & \\
Schwarz criterion & -31.69160 & &
\end{tabular}

b) Pre inflation targeting, Y: Output gap

Sample: 1978Q1 1992Q4. Included observations: 60. Standard errors in ( ) \& t-statistics in []. Equation test statistics

\begin{tabular}{lcccc} 
& Eq 1 (LNP_SA) & Eq 2 (DLNY_SA) & Eq 3 (I) & Eq 4 (DLNS) \\
R-squared & 0.768211 & 0.672499 & 0.825882 & 0.366241 \\
Adj. R-squared & 0.630391 & 0.477768 & 0.722352 & -0.010588 \\
Sum sq. resids & 0.000512 & 0.003135 & 0.010243 & 0.010335 \\
S.E. equation & 0.003720 & 0.009205 & 0.016639 & 0.016713 \\
F-statistic & 5.574000 & 3.453482 & 7.977256 & 0.971902 \\
Log likelihood & 265.0045 & 210.6500 & 175.1278 & 174.8610 \\
Akaike AIC & -8.066817 & -6.254999 & -5.070927 & -5.062032 \\
Schwarz SC & -7.263985 & -5.452167 & -4.268095 & -4.259200 \\
Mean dependent & 0.007497 & 0.001787 & 0.107710 & 0.003741 \\
S.D. dependent & 0.006119 & 0.012737 & 0.031577 & 0.016625 \\
\multicolumn{5}{l}{ Determinant resid covariance (dof adj.) } \\
Determinant resid covariance & $7.14 \mathrm{E}-17$ & & \\
Log likelihood & $1.03 \mathrm{E}-17$ & & \\
Akaike information criterion & 832.7977 & & \\
Schwarz criterion & -24.69326 & &
\end{tabular}


c) Inflation targeting period, Y: Output growth

Sample: 1993Q1 2003Q4. Included observations: 44. Standard errors in ( ) \& t-statistics in [ ].

Equation test statistics

\begin{tabular}{lcccc} 
& Eq 1 (LNP_SA) & Eq 2 (DLNY_SA) & Eq 3 (I) & Eq 4 (DLNS) \\
R-squared & 0.504821 & 0.741470 & 0.924735 & 0.617217 \\
Adj. R-squared & -0.013938 & 0.470628 & 0.845887 & 0.216205 \\
Sum sq. resids & 0.000155 & 0.000317 & 0.000581 & 0.002995 \\
S.E. equation & 0.002714 & 0.003886 & 0.005262 & 0.011943 \\
F-statistic & 0.973133 & 2.737652 & 11.72798 & 1.539150 \\
Log likelihood & 213.8563 & 198.0605 & 184.7182 & 148.6544 \\
Akaike AIC & -8.675287 & -7.957295 & -7.350826 & -5.711562 \\
Schwarz SC & -7.742642 & -7.024650 & -6.418181 & -4.778918 \\
Mean dependent & 0.006333 & 0.005905 & 0.044373 & -0.001243 \\
S.D. dependent & 0.002695 & 0.005340 & 0.013404 & 0.013490 \\
\multicolumn{5}{l}{ Determinant resid covariance (dof adj.) } \\
Determinant resid covariance & $2.33 \mathrm{E}-19$ & & \\
Log likelihood & $1.21 \mathrm{E}-20$ & & \\
Akaike information criterion & 759.2245 & & \\
Schwarz criterion & -30.32839 & &
\end{tabular}

d) Pre inflation targeting period, Y: Output growth

Sample (adjusted): 1978Q2 1992Q4. Included observations: 59, after adjustments. Standard errors in ( ) \& t-statistics in [].

Equation test statistics

\begin{tabular}{lcccc} 
& Eq 1 (LNP_SA) & Eq 2 (DLNY_SA) & Eq 3 (I) & Eq 4 (DLNS) \\
R-squared & 0.780627 & 0.441789 & 0.847416 & 0.419059 \\
Adj. R-squared & 0.614436 & 0.018901 & 0.731821 & -0.021047 \\
Sum sq. resids & 0.000485 & 0.003163 & 0.008738 & 0.009158 \\
S.E. equation & 0.003832 & 0.009791 & 0.016272 & 0.016659 \\
F-statistic & 4.697161 & 1.044695 & 7.330950 & 0.952177 \\
Log likelihood & 261.7216 & 206.3771 & 176.4023 & 175.0179 \\
Akaike AIC & -7.990562 & -6.114476 & -5.098382 & -5.051453 \\
Schwarz SC & -7.075037 & -5.198951 & -4.182857 & -4.135928 \\
Mean dependent & 0.007508 & 0.005123 & 0.108375 & 0.003349 \\
S.D. dependent & 0.006171 & 0.009884 & 0.031422 & 0.016486 \\
\multicolumn{5}{l}{ Determinant resid covariance (dof adj.) } \\
Determinant resid covariance & $8.93 \mathrm{E}-17$ & & \\
Log likelihood & $8.74 \mathrm{E}-18$ & & \\
Akaike information criterion & 823.8380 & & \\
Schwarz criterion & -24.40129 & &
\end{tabular}




\section{Norway}

a) Inflation targeting, Y: Output gap

Sample: 1993Q1 2003Q4. Included observations: 44. Standard errors in ( ) \& t-statistics in [ ].

\section{Equation test statistics}

\begin{tabular}{lcccc} 
& Eq 1 (LNP_SA) & Eq 2 (DLNY_SA) & Eq 3 (I) & Eq 4 (DLNS) \\
R-squared & 0.763592 & 0.671368 & 0.915257 & 0.539304 \\
Adj. R-squared & 0.435248 & 0.214934 & 0.797559 & -0.100552 \\
Sum sq. resids & 0.000234 & 0.001264 & 0.000823 & 0.009668 \\
S.E. equation & 0.003606 & 0.008380 & 0.006763 & 0.023176 \\
F-statistic & 2.325584 & 1.470899 & 7.776301 & 0.842852 \\
Log likelihood & 204.7359 & 167.6323 & 177.0701 & 122.8746 \\
Akaike AIC & -8.124361 & -6.437834 & -6.866822 & -4.403391 \\
Schwarz SC & -7.070067 & -5.383540 & -5.812528 & -3.349097 \\
Mean dependent & 0.005201 & 0.000367 & 0.060114 & -0.000433 \\
S.D. dependent & 0.004799 & 0.009458 & 0.015030 & 0.022092 \\
\multicolumn{5}{l}{ Determinant resid covariance (dof adj.) } \\
Determinant resid covariance & $1.66 \mathrm{E}-17$ & & \\
Log likelihood & $4.65 \mathrm{E}-19$ & & \\
Akaike information criterion & 678.9261 & & \\
Schwarz criterion & -26.13300 & &
\end{tabular}

b) Pre inflation targeting, Y: Output gap

Sample (adjusted): 1979Q2 1992Q4. Included observations: 55 after adjustments. Standard errors in ( ) \& t-statistics in [ ].

\section{Equation test statistics}

\begin{tabular}{lcccc} 
& Eq 1 (LNP_SA) & Eq 2 (DLNY_SA) & Eq 3 (I) & Eq 4 (DLNS) \\
R-squared & 0.805077 & 0.748428 & 0.741727 & 0.394579 \\
Adj. R-squared & 0.671068 & 0.575473 & 0.564165 & -0.021647 \\
Sum sq. resids & 0.001586 & 0.003143 & 0.004895 & 0.010135 \\
S.E. equation & 0.007040 & 0.009911 & 0.012368 & 0.017797 \\
F-statistic & 6.007620 & 4.327287 & 4.177274 & 0.947991 \\
Log likelihood & 209.4370 & 190.6298 & 178.4478 & 158.4322 \\
Akaike AIC & -6.779527 & -6.095629 & -5.652646 & -4.924807 \\
Schwarz SC & -5.940097 & -5.256199 & -4.813216 & -4.085377 \\
Mean dependent & 0.016664 & $-3.97 \mathrm{E}-05$ & 0.124140 & -0.002221 \\
S.D. dependent & 0.012276 & 0.015211 & 0.018734 & 0.017607 \\
\multicolumn{5}{l}{ Determinant resid covariance (dof adj.) } \\
Determinant resid covariance
\end{tabular}


c) Inflation targeting period, Y: Output growth

Sample: 1993Q1 2003Q4. Included observations: 44. Standard errors in ( ) \& t-statistics in [ ].

\begin{tabular}{|c|c|c|c|c|}
\hline & \multicolumn{4}{|c|}{ Equation test statistics } \\
\hline & Eq 1 (LNP_SA) & Eq 2 (DLNY_SA) & Eq $3(I)$ & Eq 4 (DLNS) \\
\hline R-squared & 0.756930 & 0.649365 & 0.818523 & 0.514320 \\
\hline Adj. R-squared & 0.419334 & 0.162373 & 0.566472 & -0.160235 \\
\hline Sum sq. resids & 0.000241 & 0.002076 & 0.001763 & 0.010193 \\
\hline S.E. equation & 0.003657 & 0.010739 & 0.009896 & 0.023796 \\
\hline F-statistic & 2.242115 & 1.333419 & 3.247448 & 0.762458 \\
\hline Log likelihood & 204.1246 & 156.7218 & 160.3169 & 121.7128 \\
\hline Akaike AIC & -8.096571 & -5.941901 & -6.105314 & -4.350581 \\
\hline Schwarz SC & -7.042278 & -4.887607 & -5.051020 & -3.296287 \\
\hline Mean dependent & 0.005201 & 0.007558 & 0.060114 & -0.000433 \\
\hline S.D. dependent & 0.004799 & 0.011734 & 0.015030 & 0.022092 \\
\hline \multicolumn{5}{|c|}{ Model test statistics } \\
\hline \multicolumn{2}{|c|}{ Determinant resid covariance (dof adj.) } & $6.34 \mathrm{E}-17$ & & \\
\hline \multicolumn{2}{|c|}{ Determinant resid covariance } & $1.78 \mathrm{E}-18$ & & \\
\hline \multicolumn{2}{|l|}{ Log likelihood } & 649.4497 & & \\
\hline \multicolumn{2}{|c|}{ Akaike information criterion } & -24.79317 & & \\
\hline \multicolumn{2}{|c|}{ Schwarz criterion } & -20.57599 & & \\
\hline
\end{tabular}

d) Pre inflation targeting period, Y: Output growth

Sample (adjusted): 1979Q2 1992Q4. Included observations: 55, after adjustments. Standard errors in ( ) \& t-statistics in [ ].

\section{Equation test statistics}

$\begin{array}{lcc} & \text { Eq 1 (LNP_SA) } & \text { Eq 2 (DLNY } \\ \text { R-squared } & 0.805215 & 0.468194 \\ \text { Adj. R-squared } & 0.671300 & 0.102578 \\ \text { Sum sq. resids } & 0.001585 & 0.003909 \\ \text { S.E. equation } & 0.007038 & 0.011052 \\ \text { F-statistic } & 6.012880 & 1.280560 \\ \text { Log likelihood } & 209.4564 & 184.6339 \\ \text { Akaike AIC } & -6.780231 & -5.877598 \\ \text { Schwarz SC } & -5.940801 & -5.038167 \\ \text { Mean dependent } & 0.016664 & 0.004750 \\ \text { S.D. dependent } & 0.012276 & 0.011667 \\ & \text { Model test statistics } \\ \text { Determinant resid covariance (dof adj.) } & 2.15 \mathrm{E}-16 \\ \text { Determinant resid covariance } & 2.46 \mathrm{E}-17 \\ \text { Log likelihood } & & 739.5592 \\ \text { Akaike information criterion } & -23.54761 \\ \text { Schwarz criterion } & & -20.18989\end{array}$




\section{Sweden}

a) Inflation targeting, Y: Output gap

Sample: 1993Q1 2003Q4. Included observations: 44. Standard errors in ( ) \& t-statistics in [ ]. Equation test statistics

\begin{tabular}{lcccc} 
& Eq 1 (LNP_SA) & Eq 2 (DLNY_SA) & Eq 3 (I) & Eq 4 (DLNS) \\
R-squared & 0.864402 & 0.907571 & 0.995482 & 0.860405 \\
Adj. R-squared & 0.514108 & 0.668798 & 0.983810 & 0.499783 \\
Sum sq. resids & 0.000167 & 0.000537 & $8.90 \mathrm{E}-05$ & 0.007032 \\
S.E. equation & 0.003727 & 0.006690 & 0.002723 & 0.024208 \\
F-statistic & 2.467645 & 3.800969 & 85.29050 & 2.385893 \\
Log likelihood & 212.2076 & 186.4684 & 226.0143 & 129.8780 \\
Akaike AIC & -8.191255 & -7.021290 & -8.818833 & -4.448999 \\
Schwarz SC & -6.893662 & -5.723697 & -7.521241 & -3.151406 \\
Mean dependent & 0.003833 & 0.001698 & 0.052927 & -0.002900 \\
S.D. dependent & 0.005347 & 0.011624 & 0.021401 & 0.034228 \\
\multicolumn{5}{l}{ Determinant resid covariance (dof adj.) } \\
Determinant resid covariance & $8.69 \mathrm{E}-19$ & & \\
Log likelihood & $4.81 \mathrm{E}-21$ & & \\
Akaike information criterion & 779.5275 & & \\
Schwarz criterion & -29.61489 & &
\end{tabular}

b) Pre inflation targeting, Y: Output gap

Sample: 1978Q1 1992Q4. Included observations: 60. Standard errors in ( ) \& t-statistics in [ ].

\begin{tabular}{lcccc}
\multicolumn{5}{c}{ Equation test statistics } \\
& Eq 1 (LNP_SA) & Eq 2 (DLNY_SA) & Eq 3 (I) & Eq 4 (DLNS) \\
R-squared & 0.813650 & 0.785932 & 0.784113 & 0.694027 \\
Adj. R-squared & 0.607334 & 0.548928 & 0.545096 & 0.355272 \\
Sum sq. resids & 0.000925 & 0.004628 & 0.019251 & 0.015610 \\
S.E. equation & 0.005748 & 0.012857 & 0.026221 & 0.023611 \\
F-statistic & 3.943709 & 3.316115 & 3.280572 & 2.048755 \\
Log likelihood & 247.2663 & 198.9599 & 156.1991 & 162.4896 \\
Akaike AIC & -7.175543 & -5.565330 & -4.139970 & -4.349653 \\
Schwarz SC & -6.058560 & -4.448346 & -3.022986 & -3.232669 \\
Mean dependent & 0.018415 & -0.001903 & 0.117485 & -0.005818 \\
S.D. dependent & 0.009172 & 0.019143 & 0.038877 & 0.029406 \\
\multicolumn{5}{l}{ Determinant resid covariance (dof adj.) } \\
Determinant resid covariance & $1.41 \mathrm{E}-15$ & & \\
Log likelihood & $6.70 \mathrm{E}-17$ & & \\
Akaike information criterion & 776.7057 & & \\
Schwarz criterion & -21.62352 & &
\end{tabular}


c) Inflation targeting period, Y: Output growth

Sample: 1993Q1 2003Q4. Included observations: 44. Standard errors in ( ) \& t-statistics in [ ].

Equation test statistics

\begin{tabular}{lcccc} 
& Eq 1 (LNP_SA) & Eq 2 (DLNY_SA) & Eq 3 (I) & Eq 4 (DLNS) \\
R-squared & 0.867072 & 0.924015 & 0.995539 & 0.814958 \\
Adj. R-squared & 0.523674 & 0.727720 & 0.984013 & 0.336934 \\
Sum sq. resids & 0.000163 & 0.000623 & $8.79 \mathrm{E}-05$ & 0.009322 \\
S.E. equation & 0.003690 & 0.007205 & 0.002706 & 0.027871 \\
F-statistic & 2.524978 & 4.707277 & 86.37846 & 1.704846 \\
Log likelihood & 212.6451 & 183.2016 & 226.2919 & 123.6776 \\
Akaike AIC & -8.211139 & -6.872802 & -8.831452 & -4.167166 \\
Schwarz SC & -6.913546 & -5.575210 & -7.533859 & -2.869573 \\
Mean dependent & 0.003833 & 0.008500 & 0.052927 & -0.002900 \\
S.D. dependent & 0.005347 & 0.013808 & 0.021401 & 0.034228 \\
\multicolumn{5}{l}{ Determinant resid covariance (dof adj.) } \\
Determinant resid covariance & $1.18 \mathrm{E}-18$ & & \\
Log likelihood & $6.51 \mathrm{E}-21$ & & \\
Akaike information criterion & 772.8381 & & \\
Schwarz criterion & -29.31082 & &
\end{tabular}

d) Pre inflation targeting period, Y: Output growth

Sample: 1978Q1 1992Q4. Included observations: 60. Standard errors in ( ) \& t-statistics in [ ].

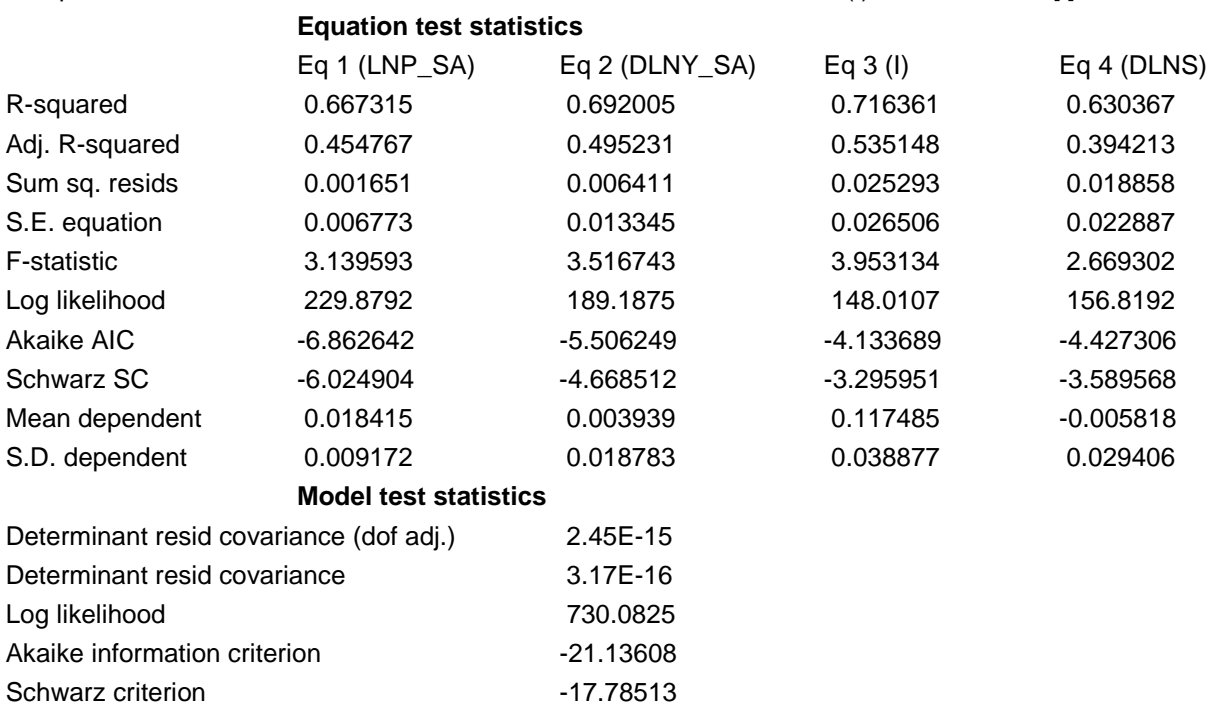




\section{Switzerland}

a) Inflation targeting, Y: Output gap

Sample: 1990Q1 2003Q4. Included observations: 56. Standard errors in ( ) \& t-statistics in [ ].

\begin{tabular}{lcccc}
\multicolumn{5}{c}{ Equation test statistics } \\
& Eq 1 (LNP_SA) & Eq 2 (DLNY_SA) & Eq 3 (I) & Eq 4 (DLNS) \\
R-squared & 0.877868 & 0.925931 & 0.990399 & 0.662905 \\
Adj. R-squared & 0.776092 & 0.864207 & 0.982398 & 0.381993 \\
Sum sq. resids & 0.000160 & 0.000525 & 0.000383 & 0.012814 \\
S.E. equation & 0.002312 & 0.004183 & 0.003575 & 0.020667 \\
F-statistic & 8.625448 & 15.00110 & 123.7853 & 2.359831 \\
Log likelihood & 277.9102 & 244.7081 & 253.5072 & 155.2506 \\
Akaike AIC & -8.996794 & -7.811005 & -8.125255 & -4.616094 \\
Schwarz SC & -8.056452 & -6.870663 & -7.184914 & -3.675752 \\
Mean dependent & 0.004496 & 0.001155 & 0.033752 & 0.003091 \\
S.D. dependent & 0.004886 & 0.011352 & 0.026946 & 0.026290 \\
\multicolumn{5}{l}{ Determinant resid covariance (dof adj.) } \\
Determinant resid covariance & $4.18 \mathrm{E}-19$ & & \\
Log likelihood & $3.44 \mathrm{E}-20$ & & \\
Akaike information criterion & 936.9808 & & \\
Schwarz criterion & -29.74931 & &
\end{tabular}

b) Pre inflation targeting, Y: Output gap

Sample (adjusted): 1981Q1 1992Q4. Included observations: 48 after adjustments. Standard errors in ( ) \& t-statistics in [].

\section{Equation test statistics}

\begin{tabular}{lcccc} 
& Eq 1 (LNP_SA) & Eq 2 (DLNY_SA) & Eq 3 (I) & Eq 4 (DLNS) \\
R-squared & 0.852195 & 0.934682 & 0.959647 & 0.540132 \\
Adj. R-squared & 0.684235 & 0.860458 & 0.913792 & 0.017555 \\
Sum sq. resids & 0.000236 & 0.000578 & 0.001232 & 0.019271 \\
S.E. equation & 0.003272 & 0.005124 & 0.007484 & 0.029597 \\
F-statistic & 5.073790 & 12.59262 & 20.92761 & 1.033594 \\
Log likelihood & 225.2859 & 203.7625 & 185.5743 & 119.5795 \\
Akaike AIC & -8.303579 & -7.406769 & -6.648930 & -3.899146 \\
Schwarz SC & -7.290012 & -6.393202 & -5.635363 & -2.885579 \\
Mean dependent & 0.008859 & 0.001233 & 0.042610 & 0.004918 \\
S.D. dependent & 0.005823 & 0.013716 & 0.025489 & 0.029860 \\
\multicolumn{5}{l}{ Determinant resid covariance (dof adj.) } \\
Determinant resid covariance & $9.63 \mathrm{E}-18$ & & \\
Log likelihood & $4.25 \mathrm{E}-19$ & & \\
Akaike information criterion & 742.8220 & & \\
Schwarz criterion & -26.61758 & &
\end{tabular}


c) Inflation targeting period, Y: Output growth

Sample: 1990Q1 2003Q4. Included observations: 56. Standard errors in ( ) \& t-statistics in [ ].

Equation test statistics

\begin{tabular}{lcccc} 
& Eq 1 (LNP_SA) & Eq 2 (DLNY_SA) & Eq 3 (I) & Eq 4 (DLNS) \\
R-squared & 0.902825 & 0.669938 & 0.990364 & 0.618072 \\
Adj. R-squared & 0.821846 & 0.394887 & 0.982333 & 0.299799 \\
Sum sq. resids & 0.000128 & 0.000624 & 0.000385 & 0.014519 \\
S.E. equation & 0.002062 & 0.004560 & 0.003582 & 0.021999 \\
F-statistic & 11.14886 & 2.435682 & 123.3280 & 1.941956 \\
Log likelihood & 284.3107 & 239.8810 & 253.4045 & 151.7543 \\
Akaike AIC & -9.225382 & -7.638607 & -8.121590 & -4.491226 \\
Schwarz SC & -8.285040 & -6.698265 & -7.181248 & -3.550884 \\
Mean dependent & 0.004496 & 0.002543 & 0.033752 & 0.003091 \\
S.D. dependent & 0.004886 & 0.005862 & 0.026946 & 0.026290 \\
\multicolumn{5}{l}{ Determinant resid covariance (dof adj.) } \\
Determinant resid covariance & $4.57 \mathrm{E}-19$ & & \\
Log likelihood & $3.76 \mathrm{E}-20$ & & \\
Akaike information criterion & 934.5030 & & \\
Schwarz criterion & -29.66082 & &
\end{tabular}

d) Pre inflation targeting period, Y: Output growth Sample (adjusted): 1981Q2 1992Q4. Included observations: 47 after adjustments. Standard errors in ( ) \& t-statistics in [ ].

\section{Equation test statistics}

$\begin{array}{lcc} & \text { Eq 1 (LNP_SA) } & \text { Eq 2 (DLN } \\ \text { R-squared } & 0.838104 & 0.793745 \\ \text { Adj. R-squared } & 0.645371 & 0.548203 \\ \text { Sum sq. resids } & 0.000222 & 0.000559 \\ \text { S.E. equation } & 0.003255 & 0.005157 \\ \text { F-statistic } & 4.348514 & 3.232622 \\ \text { Log likelihood } & 221.4432 & 199.8072 \\ \text { Akaike AIC } & -8.316732 & -7.396053 \\ \text { Schwarz SC } & -7.293246 & -6.372567 \\ \text { Mean dependent } & 0.008547 & 0.004169 \\ \text { S.D. dependent } & 0.005465 & 0.007673 \\ & \text { Model test statistics } \\ \text { Determinant resid covariance (dof adj.) } & 7.33 \mathrm{E}-18 \\ \text { Determinant resid covariance } & 2.92 \mathrm{E}-19 \\ \text { Log likelihood } & & 736.1364 \\ \text { Akaike information criterion } & -26.89942 \\ \text { Schwarz criterion } & & -22.80548\end{array}$




\section{The United Kingdom}

a) Inflation targeting, Y: Output gap

Sample: 1993Q1 2003Q4. Included observations: 44. Standard errors in ( ) \& t-statistics in [ ].

\section{Equation test statistics}

\begin{tabular}{lcccc} 
& Eq 1 (LNP_SA) & Eq 2 (DLNY_SA) & Eq 3 (I) & Eq 4 (DLNS) \\
R-squared & 0.999518 & 0.391005 & 0.922622 & 0.644015 \\
Adj. R-squared & 0.999204 & -0.007184 & 0.872028 & 0.411255 \\
Sum sq. resids & 0.000139 & 0.000298 & 0.000420 & 0.007373 \\
S.E. equation & 0.002308 & 0.003386 & 0.004018 & 0.016840 \\
F-statistic & 3174.424 & 0.981959 & 18.23596 & 2.766866 \\
Log likelihood & 216.2807 & 199.4217 & 191.8855 & 128.8362 \\
Akaike AIC & -9.012759 & -8.246440 & -7.903885 & -5.038011 \\
Schwarz SC & -8.282864 & -7.516545 & -7.173990 & -4.308115 \\
Mean dependent & 4.547490 & 0.007338 & 0.054698 & 0.003017 \\
S.D. dependent & 0.081784 & 0.003374 & 0.011232 & 0.021947 \\
\multicolumn{5}{l}{ Determinant resid covariance (dof adj.) } \\
Determinant resid covariance & $2.33 \mathrm{E}-19$ & & \\
Log likelihood & $2.84 \mathrm{E}-20$ & & \\
Akaike information criterion & 740.4685 & & \\
Schwarz criterion & -30.38493 & &
\end{tabular}

\section{b) Pre inflation targeting, Y: Output gap}

Sample: 1978Q1 1992Q4. Included observations: 60. Standard errors in ( ) \& t-statistics in [ ].

\begin{tabular}{|c|c|c|c|c|}
\hline & \multicolumn{4}{|c|}{ Equation test statistics } \\
\hline & Eq 1 (LNP_SA) & Eq 2 (DLNY_SA) & Eq $3(\mathrm{I})$ & Eq 4 (DLNS) \\
\hline R-squared & 0.779810 & 0.865583 & 0.770697 & 0.490554 \\
\hline Adj. R-squared & 0.666892 & 0.796651 & 0.653105 & 0.229299 \\
\hline Sum sq. resides & 0.001847 & 0.002441 & 0.008941 & 0.045358 \\
\hline S.E. equation & 0.006882 & 0.007912 & 0.015141 & 0.034103 \\
\hline F-statistic & 6.905983 & 12.55710 & 6.554014 & 1.877685 \\
\hline Log likelihood & 226.5211 & 218.1488 & 179.2066 & 130.4894 \\
\hline Akaike AIC & -6.850704 & -6.571626 & -5.273554 & -3.649646 \\
\hline Schwarz SC & -6.117684 & -5.838605 & -4.540533 & -2.916626 \\
\hline Mean dependent & 0.017907 & 0.001128 & 0.113502 & -0.003609 \\
\hline S.D. dependent & 0.011923 & 0.017546 & 0.025708 & 0.038846 \\
\hline \multicolumn{5}{|c|}{ Model test statistics } \\
\hline \multicolumn{2}{|c|}{ Determinant resid covariance (dof adj.) } & $6.17 \mathrm{E}-16$ & & \\
\hline \multicolumn{2}{|c|}{ Determinant resid covariance } & $1.10 \mathrm{E}-16$ & & \\
\hline \multicolumn{2}{|c|}{ Log likelihood } & 761.8173 & & \\
\hline \multicolumn{2}{|c|}{ Akaike information criterion } & -22.59391 & & \\
\hline \multicolumn{2}{|l|}{ Schwarz criterion } & -19.66183 & & \\
\hline
\end{tabular}


c) Inflation targeting period, Y: Output growth

Sample: 1993Q1 2003Q4. Included observations: 44. Standard errors in ( ) \& t-statistics in [ ].

Equation test statistics

\begin{tabular}{lcccc} 
& Eq 1 (LNP_SA) & Eq 2 (DLNY_SA) & Eq 3 (I) & Eq 4 (DLNS) \\
R-squared & 0.569461 & 0.402643 & 0.905160 & 0.631955 \\
Adj. R-squared & 0.287956 & 0.012063 & 0.843150 & 0.391309 \\
Sum sq. resides & 0.000174 & 0.000292 & 0.000515 & 0.007623 \\
S.E. equation & 0.002589 & 0.003353 & 0.004449 & 0.017123 \\
F-statistic & 2.022911 & 1.030885 & 14.59685 & 2.626085 \\
Log likelihood & 211.2303 & 199.8462 & 187.4089 & 128.1033 \\
Akaike AIC & -8.783195 & -8.265735 & -7.700403 & -5.004694 \\
Schwarz SC & -8.053299 & -7.535839 & -6.970507 & -4.274798 \\
Mean dependent & 0.006117 & 0.007338 & 0.054698 & 0.003017 \\
S.D. dependent & 0.003068 & 0.003374 & 0.011232 & 0.021947 \\
\multicolumn{5}{l}{ Determinant resid covariance (dof adj.) } \\
Determinant resid covariance & $3.48 \mathrm{E}-19$ & & \\
Log likelihood & $4.24 \mathrm{E}-20$ & & \\
Akaike information criterion & 731.6292 & & \\
Schwarz criterion & -29.98314 & &
\end{tabular}

d) Pre inflation targeting period, Y: Output growth

Sample: 1978Q1 1992Q4. Included observations: 60. Standard errors in ( ) \& t-statistics in [ ]. Equation test statistics

\begin{tabular}{lcccc} 
& Eq 1 (LNP_SA) & Eq 2 (DLNY_SA) & Eq 3 (I) & Eq 4 (DLNS) \\
R-squared & 0.754819 & 0.542590 & 0.757135 & 0.488823 \\
Adj. R-squared & 0.629085 & 0.308021 & 0.632589 & 0.226681 \\
Sum sq. resides & 0.002057 & 0.002733 & 0.009470 & 0.045512 \\
S.E. equation & 0.007262 & 0.008371 & 0.015583 & 0.034161 \\
F-statistic & 6.003309 & 2.313137 & 6.079154 & 1.864727 \\
Log likelihood & 223.2960 & 214.7671 & 177.4828 & 130.3877 \\
Akaike AIC & -6.743199 & -6.458903 & -5.216095 & -3.646255 \\
Schwarz SC & -6.010178 & -5.725883 & -4.483074 & -2.913235 \\
Mean dependent & 0.017907 & 0.004639 & 0.113502 & -0.003609 \\
S.D. dependent & 0.011923 & 0.010063 & 0.025708 & 0.038846 \\
\multicolumn{5}{l}{ Determinant resid covariance (dof adj.) } \\
Determinant resid covariance & $7.45 \mathrm{E}-16$ & & \\
Log likelihood & $1.33 \mathrm{E}-16$ & & \\
Akaike information criterion & 756.1593 & & \\
Schwarz criterion & -22.40531 & & \\
Log likelihood & -19.47323 & & \\
Akaike information criterion & 764.3557 & & \\
Schwarz criterion & -22.54519 & &
\end{tabular}

